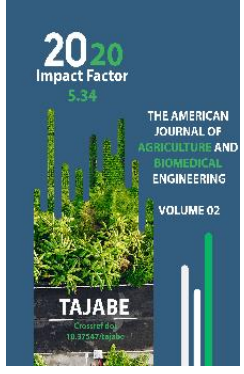

\title{
The History Of Construction Of Irrigation Facilities In The Ferghana Valley During The Second World War
}

\author{
Kabuljan Makhamadjanovich Nasritdinov \\ Candidate Of Historical Sciences, Associate Professor At The Department Of "Humanitarian \\ Sciences", Andizhan Institute Of Agriculture And Agrotechnology, Andizhan Region, Republic \\ Of Uzbekistan
}

\section{ABSTRACT}

In the state of the author on the basis of archival documents, scientific-historical sources and literature analyzes the history of the development of irrigation construction in Ferghana Valley in the years of the Second World War of the XX century.

\section{KEYWORDS}

Second World War, fascism, Ferghana Valley, agriculture, irrigation, folk construction, aqueduct, siphon, extensive development path, locomotive, dam, plenum, solution, hectare, without collector irrigation, crop rotation, canal, cubic meter, ketmen, shovel, scrap, earthworks, irrigation system, concert, irrigation, aggregates.

\section{INTRODUCTION}

During the Second World War, which left its mark on the history of mankind, the pace of irrigation construction in the Ferghana Valley, as well as in the whole of Uzbekistan, fell sharply and significantly decreased in size. The main reason for this is, firstly, the fact that the construction of all irrigation facilities built before World War II was carried out mainly by manual labor, and with the onset of the war mobilized a large part of the working population to war the supplier was converted to a database.

\section{METHODS}

Due to the war, the Central Union government made the delivery of cotton, grain, vegetables, and clothing to the front a priority for the government and workers of the 
Republic. In December 1941, the V Plenum of the Central Committee of the Communist Party of Uzbekistan (b) discussed issues in the field of military economy in wartime and identified the tasks to be performed in agriculture, in particular, in the construction of irrigation.

\section{RESULTS AND DISCUSSIONS}

In particular, the Plenum increased the area under crops in the republic in 1942 to 521.8 thousand hectares, increased grain yields to 15 million quintals instead of 5.5 million quintals in 1941, planted sugar beets on at least 70,000 hectares, and harvested an average of 19.8 quintals of cotton per hectare centner [1, p.151], only in the spring of 1942 it was planned to develop 130,000 hectares of new irrigated lands and include them in agriculture as a result of irrigation construction through the people's hashar [2. p.169]. According to the decision of the plenum, the most important thing during the war was to transform Uzbekistan from a grain-consuming republic to a grain-producing republic.

Indeed, in Uzbekistan, where agriculture is based on artificial irrigation, the expansion of arable land, meeting the needs of the army and the population in clothing and food, industrial raw materials required the expansion of direct irrigation facilities. The relocation of many industrial enterprises and the population to the republic has further increased the demand for agricultural products and electricity. This situation, as mentioned above, necessitated the reorganization of the economy of the Republic of Uzbekistan.

It was very difficult for the workers of the republic to carry out these tasks in the field of irrigation construction in wartime. First, the majority of the male population, which was the main labor resource, was mobilized on regular fronts. Second, there was a lack of specialized equipment and qualified personnel needed to build irrigation facilities. That is why the work to be done in the construction of waterworks was mainly carried out by women, the elderly, adolescents and girls. Third, there were no plans to allocate funds from the state budget for the construction of these facilities.

Therefore, the government began to implement the planned tasks on the basis of the rich experience gained in the construction of pre-war public irrigation in the construction of hydropower plants "People's Hashar Road" [3. p.189-192].

It should be noted that despite the abovementioned difficult situation, the workers of our republic did not stop their efforts for water, which began before the war, but became inseparably linked with the construction of large irrigation facilities, the victories of the army.

Uzbek peasants, their husbands, sons, fathers, teenagers and elders, who went to the front, continued to fight to turn the water-scarce lands into arable lands, realizing that the victory over fascism, the enemy of humanity, was a matter of life and death. This, in turn, was a separate battle, a separate battle, a struggle for water, which was the main natural element that provided food and clothing within the country.

During the years of World War II, the government of the republic led a nationwide movement in the struggle for water, developing and implementing measures aimed at accelerating water management. In particular, in order to develop projects and estimates for irrigation construction, to improve technical management, the organization "Sazvodproizloyiha" was merged with the trust "Uzvodproizstroy" [4. p.9].

Due to the fact that many engineers and technicians were mobilized to the front, the government allowed 3-4 students of the 
Tashkent Institute of Irrigation and Agricultural Mechanization and the Tashkent Irrigation College to be used as foremen and technicians in the construction of irrigation facilities [5. p.172].

To clarify the labor norms of the diggers involved in the construction of irrigation facilities, to write them 1.5 working days in case of full completion of daily excavation tasks, to provide 30 to 50 percent of food from the indivisible funds of collective farms to collective farms by the decision of the general meeting allowed [2.p.171]. The adoption of this decision served to ensure the participation of women, adolescents the elderly in the construction of irrigation facilities on the basis of material interests, given the lack of food during the war.

In the Republic of Uzbekistan, including the Fergana Valley, the main canals, reservoirs, dams, collector-ditches, built with a traditional hashar, coincided with the most difficult period of the war, in 1941-1942. Since 1942, a new third stage in the history of public irrigation construction has begun.

One of the largest irrigation facilities built in the Ferghana Valley during the war was the Kosonsoy Reservoir, the decision to build which was made on December 22, 1939 by the former Soviet Union. According to the decision, the water capacity of the reservoir will be 100 million cubic meters. m3. The project was built in 1940 and construction began in mid-January 1941 [6. p.337]. This reservoir would allow to improve water supply on 20,000 hectares of 56,000 hectares of arable land in the Kosonsoy-Kokseraksoy water basin, and to develop 12,000 hectares of new land [6.p.338].

Although the construction of the Kosonsoy Reservoir, whose construction history is being studied, began before the start of the war, the completion of the main work to be done in the construction coincided with the war years
1941-1945. The first stage of construction of the reservoir was completed in 1942 and involved $30 \mathrm{mln}$. cubic meters of water was planned to be accumulated, but the war that started delayed the construction of the reservoir.

At this point, we consider it appropriate to make a scientific analysis of the conclusions made in some literature on the construction of the reservoir. Some literature states that with the onset of the war, the construction of the reservoir was stopped and it was brought to a state of conservation [7.p.73]. Some literature devoted to the study of the economic problems of irrigation construction concludes that the construction of the reservoir continued during the war years [8.p.45], while others conclude that the construction of the reservoir was completed during the war years [9.p.13]. On the fourth roof of the history of the Uzbek SSR, it is written that the construction of the Kosonsoy reservoir began in late December 1941 [10.p.82].

However, the documents kept in the funds of the Central Archive of the Republic of Uzbekistan [11.p.76], Namangan regional archives state that the construction of the Kosonsoy reservoir continued during the war, only in 1943-1944 the construction fell into a semi-conservative state [12.p.10]. Some special mechanisms used in the construction of the reservoir were sent to the construction of Farkhod HPP, which began in 1943, but with the lake labor of hashar workers continued stone-picking, gravel collection, concrete pouring. If the work on the construction of the reservoir had been stopped completely, first of all, the dams that had been built earlier would have been damaged by the floods. Second, in Chust, Kosonsoy, and Turakurgan districts, the water supply would have improved somewhat and 4,000 hectares of newly developed land would not have been irrigated. Third, the Chust (western canal) 
canal would not have been built. According to archival documents, in the first quarter of 1942, an average of 3,093 hashish workers carried out earthworks in the construction of the reservoir [13.p.100]. As a result, by the beginning of April, 342 thousand cubic meters of earth were excavated and 64 thousand cubic meters of rock were laid [14.p.53]. In the summer of 1942, 7 million cubic meters of water were pumped into the reservoir as a result of year-round construction work cubic meters of water accumulation was achieved [15.p.41]. In exchange for the water stored in the reservoir, the water supply of a number of collective farms receiving water from the Kosonsoy irrigation system has been improved, about 4,000 hectares of new land have been developed, and grain crops necessary for regular army have been planted on these lands. In the spring of this year, the Chust Canal was built.

Although there are no special mechanisms in the construction of the reservoir, during 1943 the construction of the reservoir was carried out by manual labor, 18773 cubic meters of earth, $9541 \mathrm{m3}$ of stone, $2027 \mathrm{m3}$ of gravel and $347 \mathrm{m3}$ of timber [16.p.49].

On September 11, 1944, the Government of Uzbekistan adopted a special resolution "On accelerating the construction of the Kosonsoy reservoir" [6.p.338]. The resolution noted that the construction work was being carried out slowly, and in 1945 the volume of water stored in the reservoir was increased to 30 million cubic meters $\mathrm{m} 3$ and the completion of the first stage of construction is the main task for the builders. The resolution also provided for the laying of $115,000 \mathrm{~m} 3$ of stone, $15,000 \mathrm{~m} 3$ of gravel, $300 \mathrm{~m} 3$ of concrete, $15,000 \mathrm{~m} 3$ of earthworks by June 1, 1945, and 356,400 manpower Abdurahmon Musaev was appointed head of the construction of the reservoir, Professor V. Poslavsky was appointed scientific adviser.
Due to these tasks, a large amount of work was done on the construction of the reservoir due to the manual labor of hashers. As a result of the work done, at the beginning of 1945 in the reservoir 16-17 $\mathrm{mln}$. $\mathrm{m} 3$ of water was accumulated, but the construction of the first stage of the reservoir was not completed on time and the planned 30 million $\mathrm{m} 3$ of water was not accumulated in the reservoir. The height of the reservoir dam was 60.2 meters and the width was 195.2 meters [6.p.339].

The capacity of the pumping station built at the reservoir dam was $26 \mathrm{~m} 3$ per second. A canal was built to bring water from the Olabuka River to the reservoir during the winter. The length of this canal is $20 \mathrm{~km}$. The water carrying capacity was $4 \mathrm{~m} 3$. The main purpose of building this canal was to store excess water in the reservoir as a reserve during the winter. Construction of the first phase of the reservoir was completed in 1946. As a result, the amount of irrigated land in the Kosonsoy irrigation system increased by 8.3 thousand hectares.

One of the largest irrigation facilities built in the Fergana Valley during this period was the Chust Canal. The canal was to take water from Kosonsoy and supply water to Chust and Kosonsoy districts of Namangan region. The total length of the canal is $34 \mathrm{~km}$. In the territory of the Uzbek SSR, it was possible to develop 3,200 hectares of new lands and improve the water supply of old irrigated lands [2. p.173].

In early January 1942, the canal project was developed under the leadership of Sazvodproiz engineer V.I. Simakov. According to the project, the construction of the Chust canal was divided into two stages. The length of the first turn is $35 \mathrm{~km}$. from Kosonsoy to Sumsaroy, the length of the second turn was $18 \mathrm{~km}$ and continued from Sumsaroy to Govasay [2. p.174]. Construction of the canal began in 1941 at the Kosonsoy Reservoir. After the accumulation of cubic meters of water, on 
January 15, 1942, excavation work was carried out in four sections along the canal. Hashar workers from Chust, Kosonsoy, Pop and Turakurgan districts took part in the excavations. Every day, more than 7,000 people are involved in excavations. The total irrigated land area in the canal basin is 86,911 hectares, and (on the right bank of the Kosonsoy) it is irrigated through Kalmak, Chindovul, Bulakbashi and other small canals that receive water from the Kosonsoy, so there was a significant lack of water for crops during the growing season.

The first phase of the canal, which began construction, was completed on February 15, during which time it was planned to excavate $326,000 \mathrm{~m} 3$ of soil and perform 7,012 m3 of concrete and reinforced concrete works in the construction of structures [2. p.174]. According to the established distribution, hashers from Pop district are $9 \mathrm{~km}$ from the canal had to dig a long section. The poplars sent more than 1,000 diggers from 34 community farms to build the canal. They dug a total of 66,000 cubic meters of soil on their plots in 10 working days. Sami Nazirov, a member of the Red Partisan collective farm, set a record of 6-7 people per day. According to newspaper reports, Nazirov dug 105-110 cubic meters of soil in five days [17. p.1]. Following the example of S. Nazirov, Alamov, Shomurodov, Muminov, Rasulov, Soliev, Nurmatov, Botirov also worked selflessly in the construction of the canal [18. p.376].

A total of 630,000 cubic meters of earth was excavated during the construction of the first stage of the Chust canal. With the launch of the canal in 1942, a total of 2,600 hectares were irrigated, including 1,657 hectares in Chust district, 285 hectares in Kosonsoy district and 658 hectares in Olabuka district of Kyrgyzstan. In 1943, the canal allowed to irrigate 3,086 hectares of land in Chust and Kosonsoy districts.
As a result of the work carried out in the field of water resources in Namangan region in 1942, a total of 17,820 hectares of new lands were developed [19. p.14]. According to the act on the construction of the Chust canal, a total of 35 structures (bridge, dump, water distribution) were built at the facility [20. p.83]. The buildings were built on a temporary basis, mainly using local building materials, due to the lack of materials during the war. During the war, the development of new lands in the Uchkurgan desert, irrigation work continued. On December 22, 1941, the Government of the Republic adopted a resolution "On the construction of the Upper Uchkurgan Canal on state farm lands in Elektrorass."

On behalf of the regional department of water resources, a special research and design team led by engineer P.F. Kuznetsov prepared the project of the canal. According to the project, the length of the canal is $16.5 \mathrm{~km}$. to build it, it is planned to carry out excavations in the volume of $326071 \mathrm{~m} 3$ (including at the expense of 50 thousand cubic meters of rock and gravel), for which it is planned to spend 200,000 working days. The construction period was set at one month, i.e. from 15 January to 15 February 1941 [20. p.84]. Kochkor Asronbaev was appointed head of the construction, P.F. Kuznetsov was appointed chief engineer.

The canal to be built was divided into three large sections, and the excavations were carried out by collective farmers from Uchkurgan, Uychi and Naryn districts. The construction of the canal was started on January 13 by residents of Uchkurgan district. From the beginning of excavations to January $25,54,954$ cubic meters of earthworks were carried out. To do this, 6539 hashers were involved in the construction of the canal every day and an average of 56243 working days were completed [21. p.100]. In particular, excavations in the rocky section of the canal 
(headed by A.V. Korabeynikov) were carried out in extremely difficult meteorological conditions [22. p.13-14], but despite these difficult conditions, the construction of the canal was completed and commissioned on time. With the water of the Upper Uchkurgan canal, 2,086 hectares of new land have been developed and the water supply of 600 hectares of arable land in the 6th section of the Naryn state farm has been improved.

In 1943, the dams of the canal were considerably strengthened and $80 \mathrm{~cm}$ in $35-40$ pickets re-excavation was carried out at depth [20. p.85]. In 1944, the canal was extended by another $4 \mathrm{~km}$, and the water supply of an additional 564 hectares was improved. Thus, the Upper Uchkurgan canal, a semiengineered irrigation facility, was completed. During the war years, one of the most waterscarce areas in the Fergana Valley was the Oltiariq district, as water supply to the region improved somewhat with the Great Ferghana Canal, but water scarcity remained one of the most pressing problems of daily life.

It was necessary to improve the water supply of irrigated lands in the south-western oases of the Ferghana Valley, to connect the SokhShohimardon rivers to develop new lands. Thus, the project of the canal was developed and approved on December 30, 1941 by the Scientific and Technical Council. According to the project, the length of the SokhShohimardon canal will be $55 \mathrm{~km}$. in which 720,000 cubic meters of soil had to be excavated. The total cost of the work to be performed was 2133.9 (including 2079.0 at the expense of the population) thousand soums [23. p.35]. The main part of the canal starts from the Vaqf stream to the village of Kashkadarya, and then through the Povulgan stream to the steppe. When the canal is completed, its maximum capacity will be 15 cubic meters per second. According to preliminary estimates, the canal was to irrigate 9,707 hectares of land [24. p.28].
According to the administrative boundaries of that time, Altiyarik, Margilan, Fergana, Tashlak and Kuva districts of the region were included in the Sokh-Shohimardon irrigation system. Although the Greater Ferghana, Northern, and Southern Ferghana canals improved water supply on several thousand hectares of land in these districts, the lack of water during the growing season on lands not adjacent to the canals negatively affected cotton and grain yields. Therefore, the construction of this canal was of great economic importance.

On February 25, 1942, mass excavations began in the canal valley. On that day, 17,000 hashers worked. The Altiyariks were the first to start the work, digging 10,931 cubic meters of soil on the plot allotted to them, completing 40 percent of the plan in one day.

A total of 720,000 cubic meters of earth was excavated during the construction of the canal. 900 cubic meters of excavations were carried out on the lands associated with the construction of the canal with the help of blasting equipment, 23.9 thousand cubic meters with the help of special mechanisms. On average, 24-26 thousand hashers work in the canal every day, and a total of 480 thousand working days are spent.

The width of the canal ranged from 2.5 meters to 10 meters depending on the relief of the irrigated lands, and the depth ranged from 3.5 meters to 10 meters. According to the project, 17 hydraulic structures and 12 bridges were built along the canal. This work was mainly done by hand, using local building materials. 4 waterfalls and several dams were built on the Kokand section of the canal. At the Altiyarik section, 9 pipes and gutters were installed. The longest 40-meter pipe was laid near the old Arab village. The canal was opened on June 13, 1942, and from July 1, 1942, the canal was allowed to carry 15 cubic meters of water per second in the amount specified in the project. 
With the construction of the SokhShohimardon canal, the water supply of collective farms in the Oltiariq and partly Kokand irrigation districts has been radically improved. As a result, more than 9,000 hectares of cotton and grain fields were irrigated [2. p.175]. The construction of the Sokh-Shohimardon canal not only improved water supply on several thousand hectares of land, but also provided an opportunity to develop new lands from the steppe. As a result, the area under crops in the region increased by 24,400 hectares. In 10 days from May 15 to May 25, 1942 in Ferghana region in the $13.5 \mathrm{~km}$ Khorozota steppe was built a canal for the development and irrigation of 1,000 hectares of new land. In addition to the collective farmers, city workers and even schoolchildren took part in the construction of the canal. According to K.N. Sinyavsky, the head of the canal construction, the townspeople went to the hashar even after work. One water distributor was built every 800 meters of the canal. During the entire construction, 36,105 cubic meters of soil were excavated [2.p.176].

\section{CONCLUSION}

The work carried out in the water economy of the Ferghana Valley during the war years was mainly focused on the construction of the above-mentioned hydraulic structures by traditional hashar and the main focus was on the quantitative increase of arable land.

\section{REFERENCES}

1. National Archive of Uzbekistan (NAUz), Fund 58, List 17, Case 26, Pages 244.

2. Nasritdinov K.M. History of irrigation of the Fergana valley (In Uzbek) T: Yangi asr avlodi, 2009. P-224.

3. Nasritdinov K.M. History of folk lines (On the example of the Fergana Valley) // RF. Samara Scientific Bulletin, 2020. Volume 9. № 1 (30), P.189-192.

4. NaUz, Fund 2510, List 1, Case 468, Page 9.
5. NaUz, Fund 2510, List 1, Case 11, Page 172

6. Nasritdinov K. M., Urolov S. From the history of construction of Kosonsoy (Middle-Tukai) reservoir // Proceedings of the international scientific conference "History of the Fergana Valley in new research". -Fergana, 2019. p.-406.

7. Akramov Z. Namangan region (economicgeographical essay). -T., 1995. -p.73.

8. Mamedov N.M. Irrigation of Central Asia (economic essay).- M., 1969. -p.145.

9. Jabborov N. Economic problems of irrigation and development of new lands. -T., 1969. - $p 132$.

10. History of the Uzbek SSR. T. IV. -T., 1968. p. 82.

11. NaUz, Fund 2483, List 1, Case 25, Page 76.

12. Namangan regional archive, fund 275 , list 1, case 110, page 10.

13. NaUz, Fund 2483, List 1, Case 14, Sheets 54, 100.

14. NaUz, Fund 2483, List 1, Case 14, Page 53.

15. NaUz. Fund 2483, List 1, Case 14, Page 41.

16. NaUz, Fund 2483, List 1, Case 9, page 49.

17. Stalin's truth. January $28,1942$.

18. Presidency Administration archive of the Republic of Uzbekistan, Fund 58, List 18, Case 614, Page 376.

19. NaUz, Fund 2510, List 1, Case 447, Page 14.

20. Kosimov Y. From the history of irrigation of Namangan oasis. T .: "Fan" 1988. p-122.

21. NaUz, Fund 2483, List 1 , Case 149, Page 100.

22. Archive of Namangan region. Fund 5 , List 7, Case 7, Pages 13-14.

23. Archive of Fergana region, fund 1022, list 1 , case 87 , page 35 .

24. Archive of Fergana region, fund 1022, list 1 , case 87 , page 28 .

25. Hamadova N.Sh. Activity of the Communist Party of Uzbekistan in the restoration and further development of irrigation of the republic in the fourth five-year period (1946-1950): Dissertation for the degree of candidate of historical sciences. -T., 1975. -p. 34. 